\title{
Variations in growth and genetic properties of Zea mays L. germinants exposed to cold shock
}

Beckley Ikhajiagbe ${ }^{1}$, Vona D. Odenore ${ }^{1,2}$, Josiah E. Ifie ${ }^{1,3^{*}} \mathbb{D}$, Esther O. Umeokeke ${ }^{1}$, Pieter-Jan Loveniers ${ }^{4}$ and Peace I. Enaruna'

\begin{abstract}
Background: Abiotic stresses like low temperatures are contributory factors to the variations observed among species during plant germination, growth, and development. The present study evaluated the morphological and genetic responses of maize (Zea mays L.) seedling to cold shock induced by a one-time exposure to low temperature. Seeds were originally exposed to distilled water at room temperature for $48 \mathrm{~h}$ before they were completely submerged in buckets of ice for $0.5,1.5,3,6$, and $12 \mathrm{~h}$, respectively, and then transferred into Petri dishes. The set up was left on the laboratory bench for an additional 5 days, and plant germination parameters were measured. DNA was extracted and this was followed by RAPD—-polymerase chain reaction.

Results: Significant growth impairment upon exposure to cold shock corresponding to the length of time of exposure was shown. The length of the prominent root significantly reduced upon exposure to a cold shock from $141.8 \mathrm{~mm}$ to as low as $91.4 \mathrm{~mm}$ in those plants exposed at $1.5 \mathrm{~h}$. The length of the prominent leaf also significantly reduced from $100.6 \mathrm{~mm}$ in the control to between 62.6 and $85.5 \mathrm{~mm}$ in low-temperature-exposed plants $(p<0.05)$, notwithstanding the time of exposure. There were significant reductions in final germination percent in the lowtemperature-exposed germinants (35.8-60.5\%) when compared to the control (88.5\%). The RAPD marker (OPA04) revealed variations in germinated maize seeds after treatment with different duration of low temperatures. The test plantlets treated for $0,0.5$, and $1.5 \mathrm{~h}$ have an unrecognizable complementary sequence to the primer OPA04, whereas the primer amplified regions of the genome of test plantlets treated for 3, 6, and 12 h. Primer OPA05 also presented diversity among maize seedlings stressed for various durations of cold shock.
\end{abstract}

Conclusion: The existence of genetic variations in the present study has far-reaching effects on the development of maize exposed to varying degrees of cold stress. Though restricted to germination only, they are important because the development of plants begins at the germination stage. These changes may affect the characteristics of economic importance or perhaps impact on the physiology of the maize plant eventually.

Keywords: Cold shock, Low temperature, Maize (Zea mays L.), RAPD, Genetic diversity, Polymorphism

\footnotetext{
* Correspondence: josiahifie@gmail.com

'Department of Plant Biology and Biotechnology, University of Benin, Benin

City, Nigeria

${ }^{3}$ Biochemistry Department, Kampala International University, Western

Campus, Ishaka, Uganda

Full list of author information is available at the end of the article
}

\section{Springer Open}

(c) The Author(s). 2020 Open Access This article is licensed under a Creative Commons Attribution 4.0 International License, which permits use, sharing, adaptation, distribution and reproduction in any medium or format, as long as you give appropriate credit to the original author(s) and the source, provide a link to the Creative Commons licence, and indicate if changes were made. The images or other third party material in this article are included in the article's Creative Commons licence, unless indicated otherwise in a credit line to the material. If material is not included in the article's Creative Commons licence and your intended use is not permitted by statutory regulation or exceeds the permitted use, you will need to obtain permission directly from the copyright holder. To view a copy of this licence, visit http://creativecommons.org/licenses/by/4.0/. 


\section{Background}

Plants form a critical piece of the diet of humanity. It is also believed that perhaps without plants the ecological food chain may not be entirely complete for the earth. However, environmental changes affect not only plant distribution, but also available even in areas where they were originally found to be naturally present (Ikhajiagbe and Omoregie 2020). This situation spells doom for food security across the globe. Agriculture and food security may be impacted by climate change globally. Most of the crops cultivated for food globally are grown in the tropics where productivity is significantly affected by atmospheric fluctuations. Most societies may not be able to mitigate the negative impacts of climate changes on the production of foods, maintenance of food quality, and adequate supply under socio-economic pressures (Ikhajiagbe and Omoregie 2020).

Currently, the agricultural sector in Nigeria is being transformed to meet food demands through an increase in the production capacity of most of these commodity crops (Iloh et al. 2014). Globally, maize (Zea mays L.) is ranked as one of the most useful cereals especially due to its valuable source of raw material for many industrial products (Dowsell et al. 1994). It is known to exceed all other cereal crops in Nigeria in terms of annual production and productivity (CSA, 2008). It is a staple food consumed by about $50 \%$ of the population of subSaharan Africa and is one of the priority crops to feed the ever-increasing population of the country (Iloh et al. 2014). In the developing world, the importance of maize cannot be overemphasized and this includes the potential to alleviate or mitigate the present food insecurity and poverty. Maize is a crop having a short life cycle, which requires warm weather and appropriate management. The forest ecology in Nigeria is where most of the maize is grown, but due to higher yield potential, it is produced in the northern Guinea savannah in large scale capacity. However, with the increasing threat of erratic weather conditions, the question would be what impact would a rather significantly low temperature have on maize development as well as genetic properties?

Ordinarily, low temperatures affect different aspects of the growth of crops; photosynthetic and mitotic abilities necessary for their survival and reproduction, water assimilation, and transport for their growth and yields. The cell changes that are prompted by temperature changes include reactions that lead to the accumulation of harmful compounds, particularly reactive oxygen (ROS) (Mittler, 2002). Improved photosynthetic electron transition to oxygen and a significant decrease of the respiratory electron transport chain can likewise result in oxidative stress from the accumulation of ROS during chilling (William et al. 2004). Plants have adopted a variety of responses to changes in temperature in order to limit damages and ensure that cell homeostatic processes are maintained (Kotak et al. 2007). Distinctive plant ponders have uncovered that improving antioxidant defense is a strategy that induces tolerance to stress caused by abnormal temperature changes (Huang and Guo 2005). Seed germination is profoundly subject to temperature because it is one of the fundamental essentials of the germination process. In any case, the scope of temperature wherein seeds perform better germination depends to a great extent on crop species (Yuan and Wen 2018).

Plant germination begins with the take-up of water by inactive dry seeds and ends with the lengthening of the embryonic axis (Bewley and Black 1994). Germination alludes to the process by which the organism develops either from seed or comparable structure. The most common cases of germination include the growth of a seedling from a seed of either an angiosperm or gymnosperm (Alvarado and Bradford 2002). Natural factors have been shown to affect seed germination (Rizzardi et al. 2009). The periodicity of seed germination has been shown to be significantly affected by temperature changes especially low temperature which generally influences plant development and the profitability of crops and prompts generous crop misfortunes (Xin and Browse, 2000; Wahid et al., 2007; Guan et al. 2009). Studies have shown that plants which originate from temperate regions are tolerant to chilling effects when compared to those of tropical and subtropical origins which do not have such an adaptative mechanism to a cold environment (Xin and Browse 2000; Sanghera et al. 2011).

The physiological processes of plants are to a great extent influenced by the change of environmental temperature. The capacity of plants to adapt to an extreme temperature is a process that is complex and dictated by ecological elements and by the hereditary ability of the plant (Balkaya 2004). Generally, exposure to cold temperature influences crop development and growth in two different ways concurrently. First, the development events in the shoot apex are influenced which legitimately decide the differentiation of the panicle and subsequently potential yield and spikelet fertility leading to fewer grains. Secondly, photosynthesis is impeded which hinders growth and results in indirect yield because there is less sugar accessible for grain production (Takeoka 1992). Gan et al. (2004) observed that cold stress prompted morphological side effects like a stunted plant, bushy plants, premature development, and yellowing of leaves. During chilling stress decrease in ribosomal numbers, dilation of the endoplasmic reticulum, and vesiculation of the cytoplasmic membrane was observed (Ishikawa 1996). The outcome of cold stress quickened senescence and plant death (Sharma et al. 2001). The investigation of the effects of non-lengthy exposure of maize germinants to low temperatures on its growth and genetic disposition, 
using RAPD has become necessary and also, due to the need of increasing maize production in the face of climate change, this study was to determine variations in phenotypic and genotypic responses of maize seedling exposed to cold shock for improved knowledge and resources in breeding programs.

\section{Material and methods}

The experiment was carried out in the pre-degree laboratory of the Department of Plant Biology and Biotechnology, University of Benin, Benin City. At the end of the experiment, seed drying was carried out at the Faculty of Agriculture Laboratory, University of Benin.

\section{Initiation of germination and exposure to cold shock}

Germination initiation was achieved by placing dry viable seeds in Petri dishes for $48 \mathrm{~h}$ on tissue paper that was originally moistened with distilled water. Ten seeds were placed on each Petri dish. The 10 seeds each that were placed into the Petri dishes were removed from the Petri dishes and immediately transferred to ice cubefilled transparent buckets $(40 \mathrm{~cm}$ in height, $22 \mathrm{~cm}$ in diameter). Crushed ice was first placed in the buckets and made to the $10 \mathrm{~cm}$ mark of the transparent buckets before maize seeds were placed carefully, and then, ice cubes were placed over seeds till the transparent bucket was full of ice block.

\section{Replacement and time intervals}

The ice in the transparent buckets was continually being replaced with more ice cubes as soon as they melted, till the time frame specified for each treatment was achieved. Seeds were left in the ice buckets for $0.5,1.5$, 3,6 , and $12 \mathrm{~h}$, respectively, before they were carefully removed and transferred into Petri dishes. It should be noted that the control was not exposed to ice.

\section{Placement in Petri-dishes}

Upon exposure of seeds to ice (cold) at different time intervals in the transparent buckets, they were later removed and placed back into the Petri dishes after completion of the time frame for exposure to cold. Petri dishes were replicated thrice.

\section{Germination parameters and chlorophyll content (CCl)}

Plant germination parameters measured were root length, plant height, length of prominent root, and length of the prominent leaf. Wet weights of roots, leaves, and those of seedlings were measured using the weighing balance after the day of termination of the experiment. Their respective dry weights were also measured after drying in an oven at $50^{\circ} \mathrm{C}$ for 2 days. The foliar chlorophyll content index (CCI) was measured using a chlorophyll content meter according to methods described by Ikhajiagbe et al. (2017).

\section{Germination test formula}

Rate of germination index (RGI)

$$
\begin{aligned}
& \text { RGI }=\frac{\text { Number of seedlings at } 7 \text { days }}{\text { Number of seedlings at } 14 \text { days }} \times 100 \\
& \text { GRI }(\% / \text { day })=\left(G_{1} / 1\right)+\left(G_{2} / 2\right)+\ldots+\left(G_{n} / n\right)
\end{aligned}
$$

where $G_{1}$ is germination percentage (\%germ) at 1st day, $\mathrm{G}_{2}$ is \%germ at 2 days, $\mathrm{G}_{\mathrm{n}}$ is \%germ at $n$ days, divided by $n$ (no. of days for which that germ. percent was calculated).

GRI shows the \%germ on each day of the germination period.

\section{Time spread of germination (TSG)}

The TSG is the time taken between the first and last germination events which occur in a seed lot. It is measured in days and a greater difference in time difference is indicated by a higher TSG (Al-Mudaris 1998).

\section{The germination index (GI)}

The GI was calculated using the equation stated by the Association of Official Seeds Analysts (AOSA 1983) as shown below

$$
\text { GI }=\frac{\text { No. of germinated seed }}{\text { Days of the first count }}+\frac{\text { No. of germinated seed }}{\text { Days of the final count }}
$$

Higher GI indicates a higher germination percentage and rate.

\section{Coefficient of the velocity of germination (CVG)}

The CVG was determined by a mathematical equation stated by Scott et al. (1984). The equation is shown below

$$
\mathrm{CVG}=\frac{\Sigma \mathrm{Ni}}{\Sigma \mathrm{NiTi}} \times 100
$$

\section{Mean daily germination (MDG)}

The MDG which is an index of daily germination was calculated from the equation below

$$
\mathrm{MDG}=\mathrm{FGP} / \mathrm{d}
$$

\section{Mean germination time (MGT)}

The MGT which is an index of daily germination was calculated from the equation below 


$$
\mathrm{MGT}=\frac{\sum \mathrm{fx}}{\sum \mathrm{f}}
$$

where $f=$ seeds germinated on day $x$.

The lower the MGT, the faster a seed population has germinated.

\section{First day of germination (FDG)}

This was measured as the first day of germination.

\section{Prominent foliar color}

The prominent foliar color was determined using the color code downloaded from Google App Store.

\section{Determination of total sugars}

Water was added to a measured $0.1 \mathrm{ml} / 0.2 \mathrm{ml}$ of sample extract to make up $1 \mathrm{ml}$. Then, $1 \mathrm{ml}$ of phenol solution and $5 \mathrm{ml}$ concentrated $\mathrm{H}_{2} \mathrm{SO}_{4}$, were added. The resultant solution was boiled for $20 \mathrm{~min}$ in a water bath and read via UV-VIS spectrophotometer (Spectronic $21 \mathrm{D}$, England) at a wavelength of $490 \mathrm{~nm}$ after it had cooled off. A standard calibration curve was determined first from a standard solution also ran at $490 \mathrm{~nm}$ (Fig. 1).

\section{Random amplified polymorphic DNA (RAPD) polymerase chain reaction}

The RAPD-PCR was carried out according to methods described by Ikhajiagbe and Omoregie (2020). "The RAPD-PCR was carried out on the extracted DNA sample using the RAPD primer OPA 04 (5'-AAT CGG GCT G-3'). The PCR reaction was carried out in a $20 \mu \mathrm{l}$ reaction mixture containing $1 \mathrm{X}$ PCR buffer (Solis Biodyne), $2.5 \mathrm{mM}$ magnesium chloride, $0.2 \mathrm{mM}$ of each dNTP, 40 pMol of primer, $1 \mathrm{U}$ Taq DNA polymerase, 10-200 ng of DNA, and sterile deionized water was used to make up the reaction mixture. Amplification was carried out in an Eppendorf Nexus thermal cycler using the following cycling parameters; an initial denaturation at $95^{\circ} \mathrm{C}$ for $5 \mathrm{~min}$ which was followed by 40 consecutive cycles of $95^{\circ} \mathrm{C}$ for $1 \mathrm{~min}, 30^{\circ} \mathrm{C}$ for $1 \mathrm{~min}$, and $72^{\circ} \mathrm{C}$ for $2 \mathrm{~min}$. This was followed by a final extension of $72^{\circ} \mathrm{C}$ for $10 \mathrm{~min}$. The PCR products were separated on a $1 \%$ Agarose gel and $1 \mathrm{~Kb}$ DNA ladder (Fermentas) was used as DNA molecular weight standard".

\section{Statistical analysis}

The experimental design adopted for the present study was the complete randomized experimental design. Therefore, a single factor analysis of variances (ANOVA) was necessary. Results were thereafter presented in means of 5 replicates, and treatment means were separated by using Duncan multiple range test at a $95 \%$ confidence limit. Statistical analyses were performed using the SPSS $^{\circledR}$ version 23 as well as the Microsoft Excel was used where necessary.

\section{Results}

The plant height of maize germinants after exposure to cold shock has been presented in Fig. 2, where results for the control experiments showed progression in plant height from $30 \mathrm{~mm}$ on the first day to $55.5 \mathrm{~mm}$ on the 4th day after exposure to cold shock. However, when results were compared to germinants exposed to cold shock, it was observed that at the first day following plant exposure, plant heights ranged from $2 \mathrm{~mm}$ in those germinants exposed at $1.5 \mathrm{~h}$ to $10 \mathrm{~mm}$ in those germinants exposed at $6 \mathrm{~h}$. However, on the 4th day after exposure of plants to cold shock, plant height reduced from $55.2 \mathrm{~mm}$ in the control to $25.4 \mathrm{~mm}$ in germinants exposed at $0.5 \mathrm{~h}$ and $17.8 \mathrm{~mm}$ in germinants exposed at $1.5 \mathrm{~h}$.

The effects of cold shock on the root length of maize germinants have been presented in Fig. 3 below, 1 day after exposure to cold shock; root length was $3.6 \mathrm{~mm}$ for

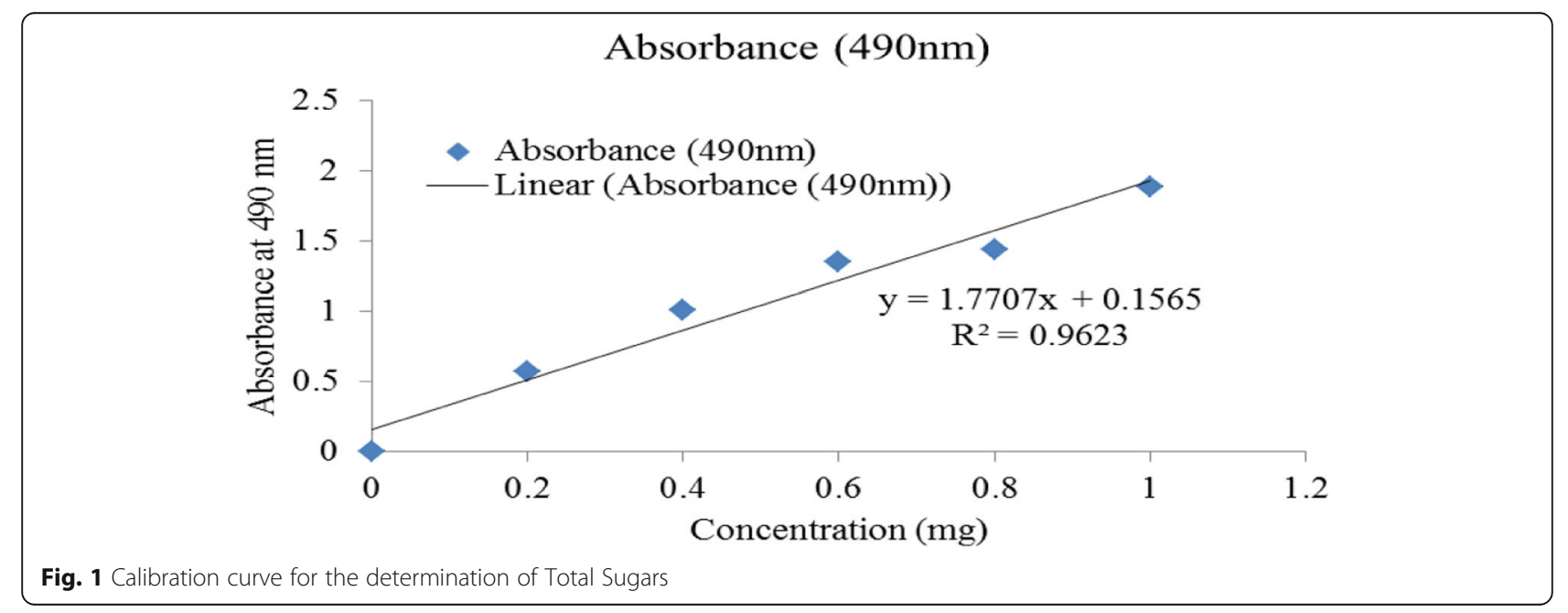




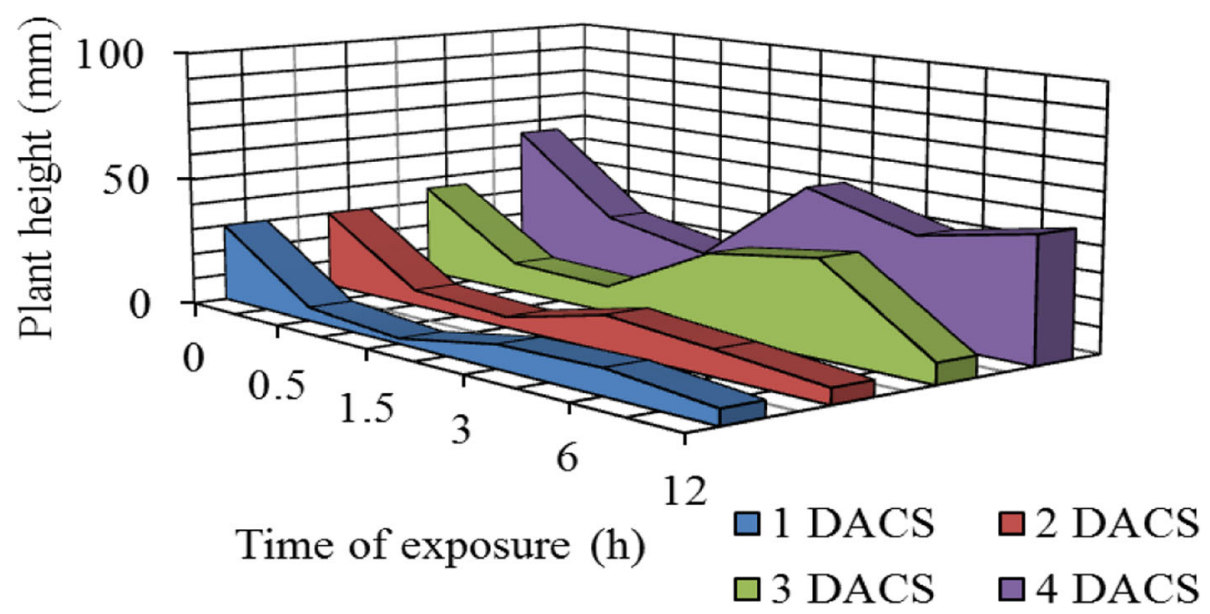

Fig. 2 Effects of cold shock on plant height of maize germinant (DACS days after exposure to cold shock)

seedlings exposed at $0.5 \mathrm{~h}$ and $8 \mathrm{~mm}$ for those exposed at $12 \mathrm{~h}$, compared to $9.2 \mathrm{~mm}$ in the control. However, 4 days after exposure to cold shock root length was highest in the control $(74.2 \mathrm{~mm})$ and significantly reduced in the seedlings exposed to cold shock with values ranging from $(24.6-40.2 \mathrm{~mm})$.

Table 1 and Plate 1 show the effects of cold shock on germination parameters of the maize plants at 7 days after germination was initiated (or the 5th day after plants were exposed to cold shock). The length of prominent root significantly reduced upon exposure to the cold shock from $141.8 \mathrm{~mm}$ to $91.4 \mathrm{~mm}$ in those germinants exposed for $1.5 \mathrm{~h}$. The length of the prominent leaf also was insignificantly reduced from $100.6 \mathrm{~mm}$ in the control plant to between 62.6 and $85.5 \mathrm{~mm}$ when germinating seeds were exposed to cold shock irrespective of the time of exposure. However, exposure of plants to cold shock did not significantly change the number of roots per plant in the germinants $(6-9$ roots per plant, $p$ $>0.05)$. Similarly, no significant changes in chlorophyll content index of the leaves of the germinated seeds were observed irrespective of exposure to cold shock; chlorophyll content index, therefore, ranged from 3.7 to 6.9 CCI. Results also showed that the exposure of maize plants to cold shock insignificantly changed both dry weight and wet weight of the germinated seeds as well as of the developing seedling (Table 1).

The results as presented in Fig. 4 showed that at $24 \mathrm{~h}$ (or 1 day) after exposure, the germination percentage was $40 \%$ in the control, compared to $26.7-33.33 \%$ in the exposed seeds. Final germination percent was achieved generally 5 days after exposure except for those seeds that were exposed in cold shock for more than $3 \mathrm{~h}$. Figure 5 shows the final germination percent (FGP) of

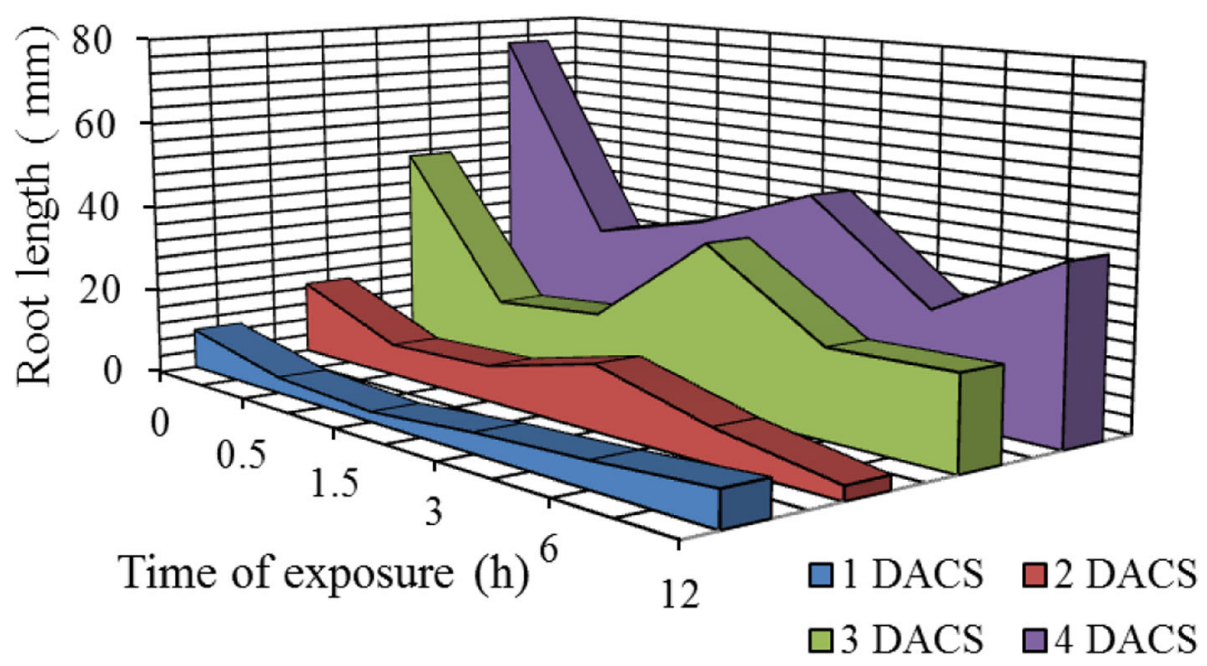

Fig. 3 Effects of a cold shock on root length of maize germinant (DACS days after exposure to cold shock) 
Table 1 Effects of cold shock germination parameters of maize at 7 days after germination initiation

\begin{tabular}{|c|c|c|c|c|c|c|c|}
\hline Parameters & Control & $0.5 \mathrm{~h}$ & $1.5 \mathrm{~h}$ & $3 \mathrm{~h}$ & $6 \mathrm{~h}$ & $12 \mathrm{~h}$ & $p$ value \\
\hline Length of prominent root $(\mathrm{mm})$ & $141.8^{\mathrm{a}}$ & $107.2^{b}$ & $91.4^{b}$ & $97.2^{\mathrm{b}}$ & $104.4^{b}$ & $108.2^{b}$ & 0.054 \\
\hline Length of prominent leaf (mm) & $100.6^{\mathrm{a}}$ & $83.6^{\mathrm{b}}$ & $62.6^{b}$ & $83.4^{b}$ & $85.5^{\mathrm{b}}$ & $76.2^{b}$ & 0.128 \\
\hline Length of sheath (mm) & $46.2^{\mathrm{a}}$ & $45.6^{\mathrm{a}}$ & $31.6^{\mathrm{a}}$ & $46.3^{\mathrm{a}}$ & $46.6^{\mathrm{a}}$ & $48.8^{\mathrm{a}}$ & 0.302 \\
\hline Number of roots ${ }^{b}$ & $6^{\mathrm{a}}$ & $9^{a}$ & $8^{\mathrm{a}}$ & $7^{\mathrm{a}}$ & $7^{\mathrm{a}}$ & $7^{a}$ & 0.429 \\
\hline Height (mm) & $78.6^{\mathrm{a}}$ & $67.7^{\mathrm{bc}}$ & $52.3^{c}$ & $76.6^{\mathrm{ab}}$ & $66.9^{b c}$ & $65.8^{c}$ & $<0.001$ \\
\hline Chlorophyll content (CCI) & $3.7^{\mathrm{a}}$ & $4.8^{\mathrm{a}}$ & $6.9^{a}$ & $5.3^{\mathrm{a}}$ & $5.6^{\mathrm{a}}$ & $4.7^{\mathrm{a}}$ & 0.082 \\
\hline Wet weight of root (g) & $0.08^{\mathrm{a}}$ & $0.06^{\mathrm{a}}$ & $0.07^{\mathrm{a}}$ & $0.08^{\mathrm{a}}$ & $0.07^{\mathrm{a}}$ & $0.04^{\mathrm{a}}$ & 0.128 \\
\hline Wet weight of seedling (g) & $0.24^{\mathrm{a}}$ & $0.25^{\mathrm{a}}$ & $0.16^{\mathrm{a}}$ & $0.19^{\mathrm{a}}$ & $0.22^{\mathrm{a}}$ & $0.21^{\mathrm{a}}$ & 0.219 \\
\hline Wet weight of leaf (g) & $0.15^{\mathrm{a}}$ & $0.15^{\mathrm{a}}$ & $0.09^{\mathrm{a}}$ & $0.25^{\mathrm{a}}$ & $0.19^{a}$ & $0.14^{\mathrm{a}}$ & 0.256 \\
\hline Wet weight of seed (g) & $0.17^{\mathrm{a}}$ & $0.26^{\mathrm{a}}$ & $0.12^{\mathrm{a}}$ & $0.23^{a}$ & $0.2^{\mathrm{a}}$ & $0.22^{a}$ & 0.186 \\
\hline Dry weight of root (g) & $0.04 a$ & $0.07 a$ & $0.05 a$ & $0.04 a$ & $0.06 a$ & $0.07 a$ & 0.267 \\
\hline Dry weight of seedling (g) & $0.05 a$ & $0.05 a$ & $0.06 a$ & $0.07 a$ & $0.05 a$ & $0.06 a$ & 0.142 \\
\hline Dry weight of leaf (g) & $0.04 a$ & $0.06 a$ & $0.08 a$ & $0.06 a$ & $0.06 a$ & $0.05 a$ & 0.464 \\
\hline Dry weight of seed (g) & $0.11 a$ & $0.11 \mathrm{a}$ & $0.14 a$ & $0.12 \mathrm{a}$ & $0.09 a$ & $0.11 a$ & 0.392 \\
\hline
\end{tabular}

Mean on a similar row with the same alphabetic superscripts do not differ from each other $(p>0.05)$

${ }^{a}$ Seeds exposed in water for 2 days prior to shock

${ }^{\mathrm{b}}$ Presented to the nearest integer

maize seeds at 7 days after exposure to cold shock. Whereas FGP was $83.3 \%$ in the control, it significantly reduced as exposure time to cold shock persisted. FGP in the seeds exposed for $12 \mathrm{~h}$ was $40.0 \%$, and this represented a $51.98 \%$ loss in germination when compared with the control. Generally, loss in germination also increased with persistence in exposure time to cold shock.

Germination indices were calculated during the course of the study and presented in both Tables 2 and 3. The time taken for the first germination to occur in the control was $29.5 \mathrm{~h}$ (Table 2). However, this time was further delayed upon exposure of the plant to cold to as much as $30.1 \mathrm{~h}$, although this delay was minimal $(p>0.05)$. However, the time taken to reach the last germination was significantly delayed when the plants were exposed to cold shock for more than $6 \mathrm{~h}$ prior to germination (116.2-134.8 h), as compared to $98 \mathrm{~h}$ in the control seedling. For such a plant also, it was observed that they did not attain $50 \%$ germination as compared to the control plant which attained 50\% germination in $80.4 \mathrm{~h}$. Table 2 also shows that the speed of germination was reduced upon exposure to cold shock; germination seed in the control was $68.9 \%$ per hour compared to $105.4 \%$ per hour in seeds exposed to cold shock for $12 \mathrm{~h}$.

The results as presented in Table 3 show that there were no significant changes in mean germination time irrespective of exposure of the plant to cold shock (111.6-116.6 h, $p$ $>0.05$ ). Similarly coefficient of the velocity of germination expressed as the number of plants per day also did not significantly differ when control seeds were exposed to cold shock. Results varied from $0.206-0.215$ per day. Germination rate as calculated in the present study however has significantly decreased from 1.6 seeds per day in the control compared to 0.5 seeds per day when exposed to $12 \mathrm{~h}$ of cold shock $(p=0.036)$. Similarly, mean daily germination also significantly increased from $12.9 \%$ per day in the control to $4.3 \%$ per day in seeds exposed for $12 \mathrm{~h}$.

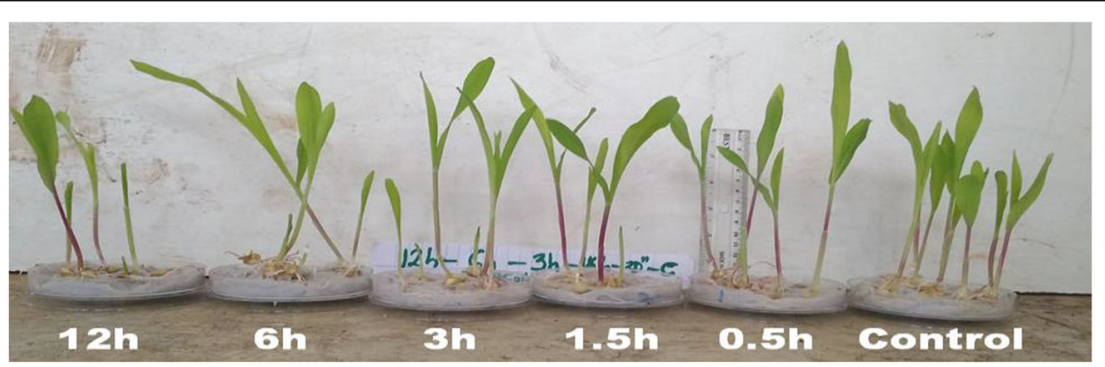

Plate 1 Experimental treatments at 7 days after germination initiation or 5 days after exposure to cold shock 


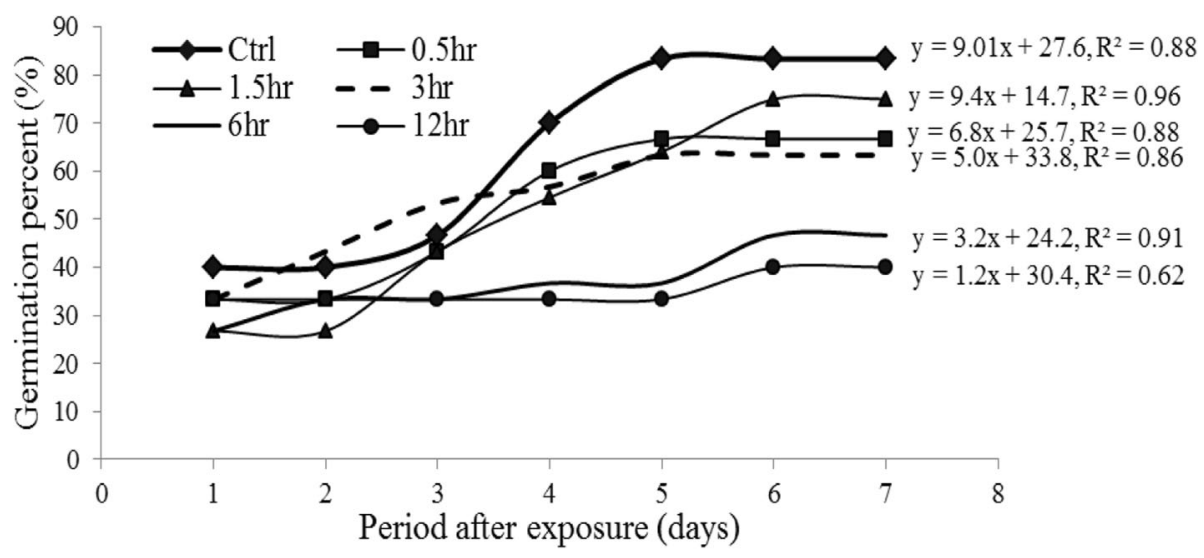

Fig. 4 Progression in germination percentages of germinant exposed to cold shock at different time intervals

Total sugars in the plumule were $5.3 \mathrm{mg} / \mathrm{ml}$ at $24 \mathrm{~h}$ after seeds were exposed to cold shock (CS) for $5 \mathrm{~h}$, compared to $6.2 \mathrm{mg} / \mathrm{ml}$ in the control. However, at $60 \mathrm{~h}$ after exposure, total sugar ranged from 13.2 to $17.3 \mathrm{mg} /$ $\mathrm{ml}$ in the seeds exposed to cold shock, compared to $20.1 \mathrm{mg} / \mathrm{ml}$ in the control (Fig. 6a). In the radicle, however, sugars ranged from 12.0 to $18.8 \mathrm{mg} / \mathrm{ml} 24 \mathrm{~h}$ after exposure to 25.4 to $31.4 \mathrm{mg} / \mathrm{ml}$ at $60 \mathrm{~h}$ after exposure, not minding the level of seed explore (Fig. 6b). Residual sugars were higher in the control $(20.3 \mathrm{mg} / \mathrm{ml})$ than in the exposed germinants $(10.3-17.2 \mathrm{mg} / \mathrm{ml})$ at $60 \mathrm{~h}$ following the exploration (Fig. 6c).

The RAPD marker presented showed variation in germinated maize seeds after treatment with different duration of low temperature (Fig. 7). The test plantlets treated for $0 \mathrm{~min}, 30 \mathrm{~min}$, and $1.5 \mathrm{~h}$ have an unrecognizable complementary sequence to the primer OPA04, whereas the regions of the genome of test plantlets treated for 3,6 , and $12 \mathrm{~h}$ were amplified by the primer. These plantlets were subjected to a long duration of stress by low temperature and may have provided some adaptive mechanism which the primer OPA04 recognized. Sample 4 ( $3 \mathrm{~h}$ of stress) had 4 bands of sizes 500, 600, 700, and 800 bp. Sample 5 (6 h) had the same 500 and $600 \mathrm{bp}$ fragments but had another 550 bp product that was absent in sample 4 . The plantlets subjected to the longest duration of cold stress in this study (sample 6) had smaller fragments of about 100, 180, and $400 \mathrm{bp}$ alongside the other bands observed in samples 4 and 5 (Fig. 7).

Primer OPA05 presented diversity among maize seedlings stressed for various durations. The banding patterns observed in Fig. 8 are different for all treatments. The fragment of about $1200 \mathrm{bp}$ was the only band common to the six treatments. Treatment 3 had only the $1200 \mathrm{bp}$ band while the others had polymorphic bands. Test plants stressed for $30 \mathrm{~min}$ had a unique fragment of $200 \mathrm{bp}$. Those stressed for the longest duration of $12 \mathrm{~h}$ had a band of about $350 \mathrm{bp}$ absent in the other treatments. There was also a $300 \mathrm{bp}$ product observed in samples that went through $3 \mathrm{~h}$ of cold stress. In comparison with the

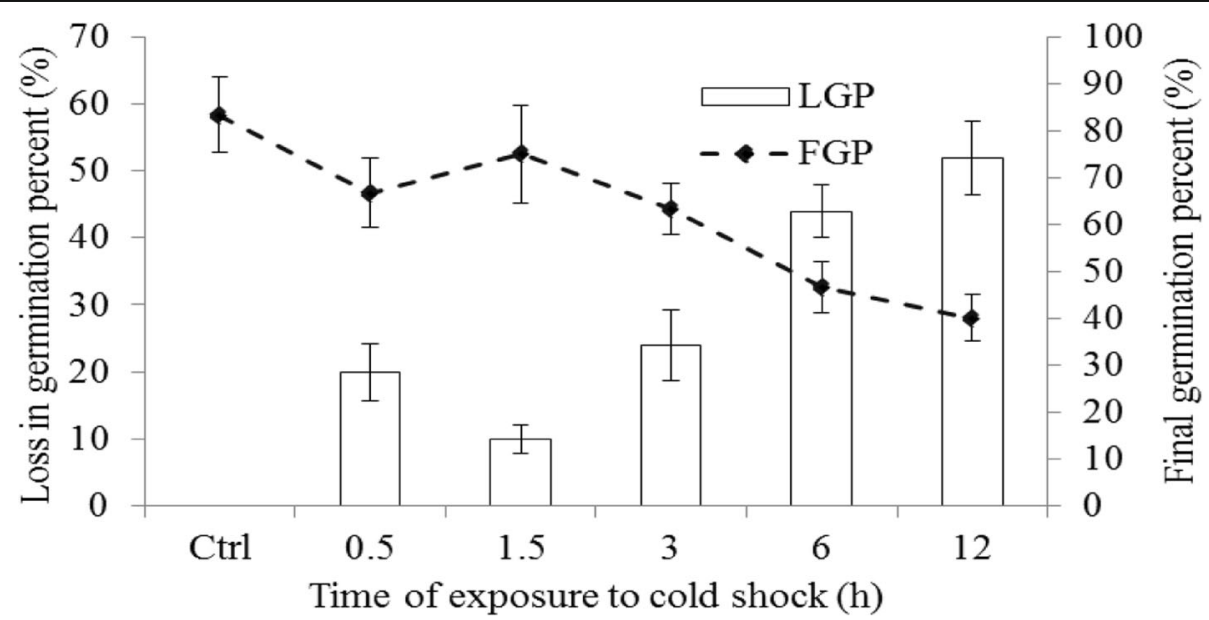

Fig. 5 Final germination percentage at 7 days after exposure to cold shock (FGP final germination percent, LGP loss in germination percent) 
Table 2 Germination index I of the test plant upon exposure to cold shock

\begin{tabular}{|c|c|c|c|c|c|c|}
\hline $\begin{array}{l}\text { Time of } \\
\text { exposure (h) }\end{array}$ & $\begin{array}{l}\text { Time for the first } \\
\text { germination to occur (h) }\end{array}$ & $\begin{array}{l}\text { Time for the last } \\
\text { germination (h) }\end{array}$ & Time for spread (h) & $\begin{array}{l}\text { Peak germination } \\
\text { time }(\mathrm{h})\end{array}$ & $T_{50}(h)$ & $\begin{array}{l}\text { Speed of } \\
\text { germination }\left(\% \mathrm{~h}^{-1}\right)\end{array}$ \\
\hline 0 & $29.5^{a}$ & $98.4^{b}$ & $68.9 c$ & $98.4^{b}$ & $80.4^{\mathrm{a}}$ & $68.9^{b}$ \\
\hline 0.5 & $30.1^{\mathrm{a}}$ & $101.6^{b}$ & $71.5^{\mathrm{b}} \mathrm{c}$ & $101.6^{b}$ & $93.6^{\mathrm{a}}$ & $71.5^{\mathrm{b}}$ \\
\hline 1.5 & $29.3^{\mathrm{a}}$ & $98.6^{\mathrm{b}}$ & $69.3 c$ & $98.6^{\mathrm{b}}$ & $95.2^{\mathrm{a}}$ & $69.3^{b}$ \\
\hline 3 & $28.5^{\mathrm{a}}$ & $91.4^{\mathrm{b}}$ & $62.9 c$ & $91.4^{\mathrm{b}}$ & $84.7^{\mathrm{a}}$ & $62.9^{\mathrm{b}}$ \\
\hline 6 & $27.6^{\mathrm{a}}$ & $116.2^{\mathrm{ab}}$ & $88.6^{b}$ & $116.2^{\mathrm{ab}}$ & $0^{\mathrm{b}}$ & $88.6^{\mathrm{ab}}$ \\
\hline 12 & $29.4^{\mathrm{a}}$ & $134.8^{\mathrm{a}}$ & $105.4^{\mathrm{a}}$ & $134.8^{\mathrm{a}}$ & $0^{\mathrm{b}}$ & $105.4^{\mathrm{a}}$ \\
\hline$p$ value & 0.310 & $<0.001$ & 0.046 & 0.128 & 0.116 & 0.033 \\
\hline
\end{tabular}

The mean on a similar column with the same alphabetic superscripts do not differ from each other $(p>0.05)$

$\mathrm{T}_{50}$ time taken for $50 \%$ of the total number of seeds to be germinated, beginning with the very moment seeds was exposed to ice ( 2 days after initiation of germination)

control (sample 1), plants stressed for $30 \mathrm{~min}, 3 \mathrm{~h}$, and 12 $\mathrm{h}$ had more similar amplified products than those stressed for $1.5 \mathrm{~h}$ and $6 \mathrm{~h}$. OPA05 presented a high level of diversity among the various duration of cold stressed maize seedlings.

There was no amplification in both the stressed maize seedlings and the control when primer OPA08 was used. This primer had no recognizable sequence in the genome of maize extracted in this study (Fig. 9).

\section{Discussions}

The result obtained from the experiment carried indicated that exposing maize germinants to cold shock had a significantly negative effect on germination. It was well noted that the control had a higher percentage of germination compared to the other maize germinates exposed to cold shock; therefore, implying that cold shock drastically reduces or slows down germination. During the course of the experiment, it was noticed that time taken to reach the last germination was significantly delayed when plants were exposed to cold shock for more than $6 \mathrm{~h}$ prior to germination. It was noticed also that no significant changes were made in mean germination time irrespective of exposure to cold shock $(p=0.613)$. The coefficient of the velocity of germination also had no significant changes $(p=0.427)$. Stress resulting from very low temperature (chilling stress) significantly affects germination, delays plant development, and reduces seedling vigor which culminate in yield loss. This stress induces deficiency in shoot water as a result of decreased uptake of water by the roots (Stewart et al. 1990; Kang and Saltvelt 2002; Wang et al. 2012).

Recent studies on maize revealed that chilling severely damaged the shoot and growth attributes, compared with control. Significant reductions in lengths of prominent leaves and roots respectively, as well as the heights of the plants, were reported. Chilling stress could also cause a necrotic lesion on leaves, delay leaf development, prolong cell cycle with decreased cell production, induce wilting, and increase susceptibility to pathogens and diseases (Korkmaz and Dufault 2001; Rymen et al. 2007). Cold shock (chilling stress) also has a negative effect on growth parameters, and the following observations were made: impaired root length and low chlorophyll index (CCI). Dry weight and wet weight were both significantly changed.

Tissue necrosis resulting from compromised membrane integrity and altered enzyme activities are negative impacts of chilling stress (Chinnusamy et al. 2007). This is related to changes in DNA, RNA, and protein structural make-up as a result of excessive ROS generation is a consequence of plant exposure to cold stress. This may be related to the ability of cold stress to induce osmotic imbalance as well as alter the plants' metabolism at its cellular level. Thus, there is a decreased amount of

Table 3 Germination index II of the test plant upon exposure to cold shock

\begin{tabular}{llllll}
\hline $\begin{array}{l}\text { Time of } \\
\text { exposure }(\mathbf{h})\end{array}$ & $\begin{array}{l}\text { Mean germination } \\
\text { time }(\mathbf{h})\end{array}$ & $\begin{array}{l}\text { Coefficient of the velocity } \\
\text { of germination }\left(\mathbf{d}^{-1}\right)\end{array}$ & $\begin{array}{l}\text { Germination } \\
\text { capacity }(\%)\end{array}$ & $\begin{array}{l}\text { Germination } \\
\text { rate }\left(\mathbf{d}^{-1}\right)\end{array}$ & $\begin{array}{l}\text { Mean daily } \\
\mathbf{g e r m i n a t i o n}^{\left(\% \mathbf{d}^{-1}\right.} \text { ) }\end{array}$ \\
\hline 0 & $116.2^{\mathrm{a}}$ & $0.207^{\mathrm{a}}$ & $90.5^{\mathrm{a}}$ & $1.6^{\mathrm{a}}$ & $12.9^{\mathrm{a}}$ \\
0.5 & $113.8^{\mathrm{a}}$ & $0.211^{\mathrm{a}}$ & $70.5^{\mathrm{b}}$ & $1.4^{\mathrm{a}}$ & $10.2^{\mathrm{ab}}$ \\
1.5 & $115.9^{\mathrm{a}}$ & $0.207^{\mathrm{a}}$ & $60.7^{\mathrm{b}}$ & $1.1^{\mathrm{ab}}$ & $8.6^{\mathrm{ab}}$ \\
3 & $111.6^{\mathrm{a}}$ & $0.215^{\mathrm{a}}$ & $50.5^{\mathrm{c}}$ & $1.1^{\mathrm{ab}}$ & $7.1^{\mathrm{ab}}$ \\
6 & $114.6^{\mathrm{a}}$ & $0.211^{\mathrm{a}}$ & $40.5^{\mathrm{c}}$ & $0.8^{\mathrm{bc}}$ & $5.7^{\mathrm{bc}}$ \\
12 & $116.6^{\mathrm{a}}$ & $0.206^{\mathrm{a}}$ & $30.0 \mathrm{~d}$ & $0.5^{\mathrm{c}}$ & $4.3^{\mathrm{c}}$ \\
$p$ value & 0.613 & 0.427 & 0.002 & 0.036 & 0.067 \\
\hline
\end{tabular}

The mean on a similar column with the same alphabetic superscripts do not differ from each other $(p>0.05)$ 
(a)
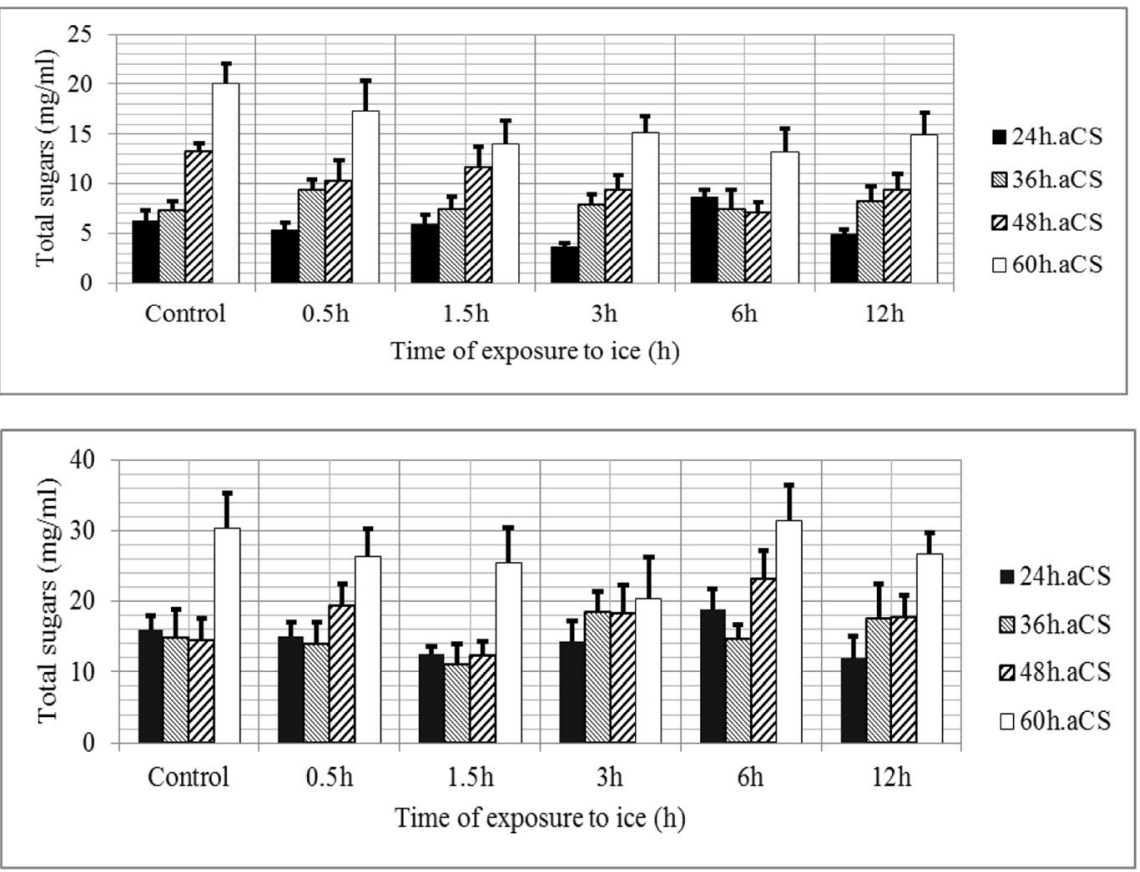

(b)

(c)

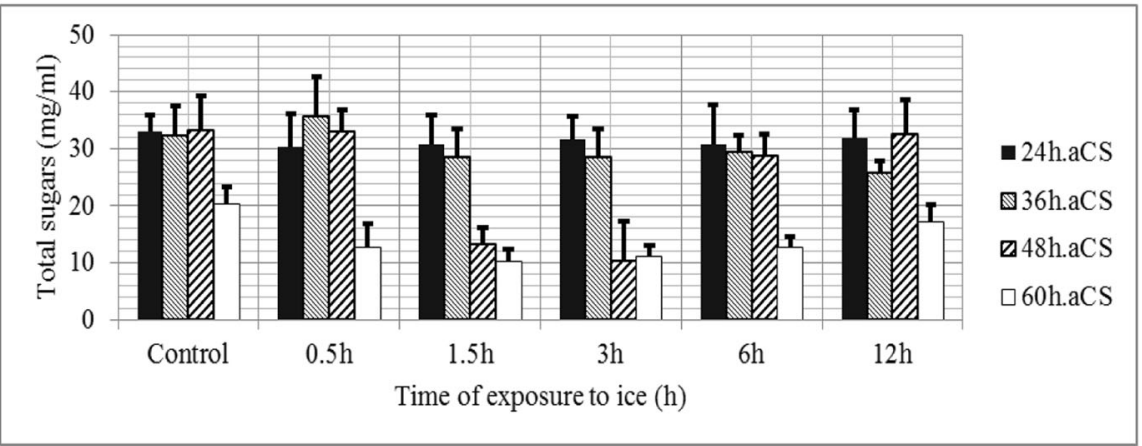

Fig. 6 Total residual sugars in maize a plumule, b radicle, and $\mathbf{c}$ germinated seed $60 \mathrm{~h}$ after exposure to cold shock regimes (h.aCS hours after exposure to cold shock)

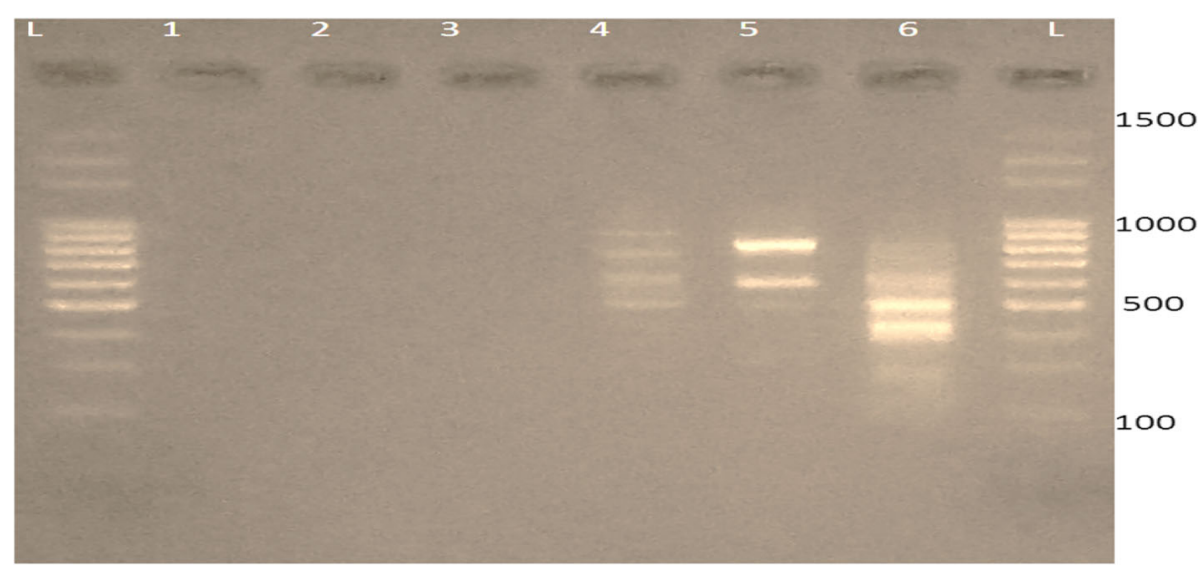

Fig. 7 RAPD-PCR gel photograph showing genetic variation using primer OPA04. Keys: L; 100 bp ladder, 1 no cold shock, 20.5 h cold shock, 3 $1.5 \mathrm{~h}$ cold shock, $\mathbf{4} 3 \mathrm{~h}$ cold shock, $\mathbf{5} 6 \mathrm{~h}$ cold shock, and $\mathbf{6} 12 \mathrm{~h}$ cold shock 


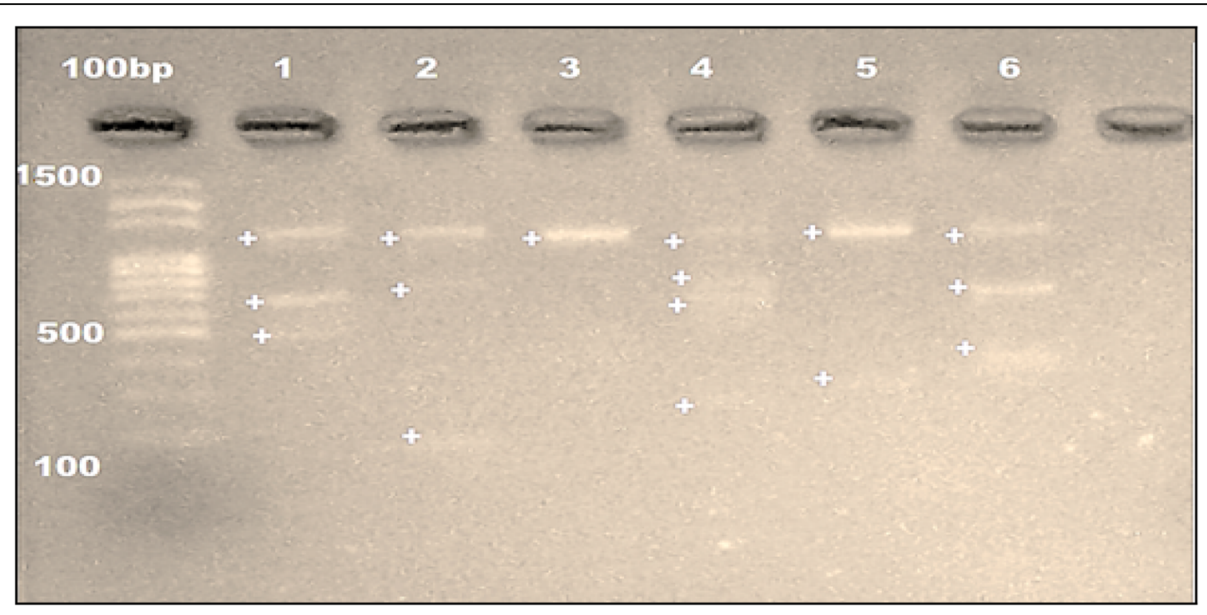

Fig. 8 RAPD-PCR gel photograph showing genetic variation using primer OPA05. Keys: L; 100 bp ladder, 1 no cold shock, 20.5 h cold shock, 3 $1.5 \mathrm{~h}$ cold shock, $\mathbf{4} 3 \mathrm{~h}$ cold shock, $\mathbf{5} 6 \mathrm{~h}$ cold shock, and $\mathbf{6} 12 \mathrm{~h}$ cold shock

produced ATP from low respiration (Sadeghi et al. 2011). To mitigate the harmful effect of oxidation caused by unfavorable conditions such as chilling, plants have developed specialized antioxidative mechanisms involving a system of enzymatic and non-enzymatic antioxidants (Gill and Tuteji 2010). It is suggested that perhaps those germinants where changes in growth parameters were compared with the control $(0.5-1.5 \mathrm{~h})$ may have grown chilling stress defense mechanism for coping with the latter; this was not determined in the study though.

The genetic diversity in $Z$. mays exposed to cold shock at different time intervals was evaluated using the RAPD molecular markers. The existence of genetic variations in the present study has far-reaching effects on the development of maize exposure to varying degrees of cold stress. These changes may affect the characteristics of economic importance or perhaps impact on the physiology of the maize plant eventually.

\section{Conclusion}

The study thus showed significant growth impairment as the time of exposure increased. The findings of the study, though restricted to germination, are critical because the development of plants begins at the germination stage. Most times, factors that impair germination eventually go on to impair the generality of the plant's growth and development. Given the fact that results presented also showed differences in genetic characteristics (via RAPD assessments) upon exposure to cold shock, it has far-reaching implications for the plants' genetic characteristics. Though the extent of genetic changes was not investigated in this study, further study is suggested to assess aspects of specific genetic characteristics that were modified by exposure to cold shock as well as a possible physiological basis for interpreting the results of the present study.

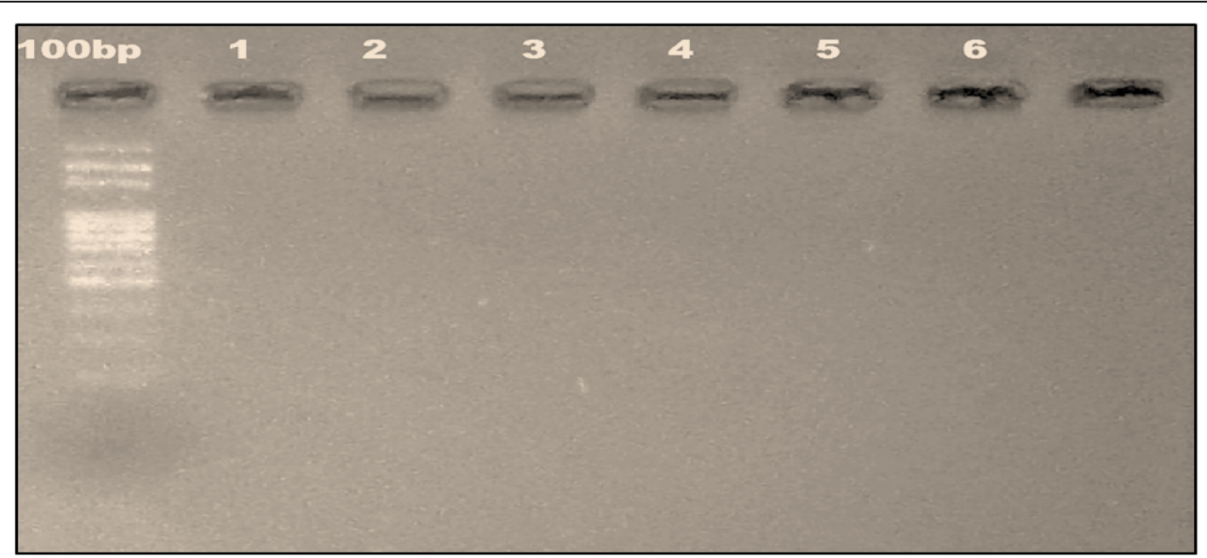

Fig. 9 RAPD-PCR gel photograph without amplification using primer OPA08. Keys: L 100 bp ladder, 1 no cold shock, 20.5 h cold shock, 31.5 h cold shock, $\mathbf{4} 3 \mathrm{~h}$ cold shock, $\mathbf{5} 6 \mathrm{~h}$ cold shock, and $\mathbf{6} 12 \mathrm{~h}$ cold shock 


\section{Acknowledgements}

The authors are grateful to the Head of Laboratory, Department of Plant Biology and Biotechnology, University of Benin, Benin City, Nigeria, for always being around when this study was conducted even during weekends.

\section{Authors' contributions}

The study was designed by BI, VDD, and supervised by BI and PL. The fieldwork was carried out by JEI, EOU, and PIE. Data collection and analysis was by VDD, JEl, EOU, and PIE. The interpretation of data analysis was by BI and PL. The authors read, revised, and approved the final manuscript.

\section{Funding}

This study was privately financed by the authors.

\section{Availability of data and materials}

The datasets used and/or analyzed during the current study are available from the corresponding author on reasonable request.

\section{Ethics approval and consent to participate}

The manuscript does not contain studies involving human participants, human or animal data, and animal or human tissue.

\section{Consent for publication}

Not applicable.

\section{Competing interests}

The authors declare that they have no competing interests

\section{Author details}

'Department of Plant Biology and Biotechnology, University of Benin, Benin City, Nigeria. ${ }^{2}$ Physiology Division Nigerian Institute for Oil Palm Research, Benin City, Edo State, Nigeria. ${ }^{3}$ Biochemistry Department, Kampala International University, Western Campus, Ishaka, Uganda. ${ }^{4}$ Faculty of Bioscience Engineering, University of Ghent, Ghent, Belgium.

Received: 2 July 2020 Accepted: 1 September 2020

\section{Published online: 17 September 2020}

\section{References}

Al-Mudaris MA (1998) Notes on various parameters recording the speed of seed germination. Der Tropenlandwlrt, BeltragezurtropischenLandwirischaft und Veterinarmedizin. Jahrgang, Oktober 98, pp 141-154

Alvarado V, Bradford KJA (2002) Hydrothermal time model explains the cardinal temperatures for seed germination. Plant Cell and Environ 25(8):1061-1069

Association of Official Seed Analysis (AOSA) (1983) Seed vigor testing handbook. Contribution No.32 to the handbook on seed testing.

Balkaya A (2004) Modelling the effect of temperature on the germination speed in some legume crops. J Agronomy 3:179-183

Bewley JD, Black M (1994) Seeds: physiology and development and germination. (New York plenum press)

Chinnusamy V, Zhu J, Zhu JK (2007) Cold stress regulation of gene expression in plants. Trends in Plant Science 12:444-451

CSA (2008) Agricultural sample survey reports on area and production of major crops for rural private peasant holdings. Stat Bull 271:18-19

Dowswell CR, Paliwal RL, Cantrell RP (1994) Maize in the Third World. West view Press, Inc, Colorado

Gan Y, Angadi SV, Cutforth HW, Potts D, Angadi W, Mc-Donald CL (2004) Canola and mustard response to short period of high temperature and water stress at different developmental stages. Can J Plant Sci 84:697-704

Gill SS, Tuteja N (2010) Reactive oxygen species and antioxidant machinery in abiotic stress tolerance in crop plants. Plant Physiol Biochem 48:909-930

Guan UJ, Hu J, Wany XJ, Shao CX (2009) Seed priming with chitosan improves maize germination and seedling growth in relation to physiological changes under low temperature stress. J Zhejianguni Sci B 10:427-433

Huang M, Guo Z (2005) Responses of antioxidant system to chilling stress in two rice cultivars differing in sensitivity. Biologia Plantarum 49:81-84

Ikhajiagbe B, Anoliefo GO, Ohanmu EO, Omoregie GO, Uwagboe T (2017) Investigating plant growth and physiological response to soil wetting with grey water under different shade regimes: a case of fluted pumpkin (Telfairia Occidentalis). Electron J Polish Agric Univ 20(4):1-12
Ikhajiagbe B, Omoregie UE (2020) Growth, yield, genetic parameters and random amplified polymorphic DNA (RAPD) of five rice varieties treated with sodium azide and sown under different saline conditions. Bull Natl Res Cent 44:89. https://doi.org/10.1186/s42269-020-00344-6

Iloh AC, Omata G, Ogbadu GH, Onyenekwe PC (2014) Effect of elevated temperatures on seed germination and seedling growth on three cereal crops in Nigeria. Sci Res Essays 9(18):806-813

Ishikawa HA (1996) Ultrastructural features of chilling injury: injured cells and the early events during chilling of suspension cultured mung bean cells. American Journal of Botany 83:825-835

Kang HM, Saltveit ME (2002) Effect of chilling on antioxidant enzymes and DDPH-radical scavenging activity of high - and low - vigour cucumber seedling radicles. Plant Cell Environ 25:1233-1238

Korkmaz A, Dufault RJ (2001) Developmental consequences of cold temperature stress at transplanting on seedling and field growth and yield in Watermelon. J Am Soc Horticult Sci 126:404-409

Kotak S, Larkindale J, Lee U, von Koskull-döring P, Vierling E, Scharf KD (2007) Complexity of the heat stress response in plants. Curr Opin Plant Biol 10:310-316

Mittler R (2002) Oxidative stress, antioxidants and stress tolerance. Trends in Plant Science 7:405-410

Rizzardi MA (2009) Effects of cardinal temperature and water potential on morning glory (triloba) seed germination. Planta Daninha 27(1):13-21

Rymen B, Fiorani F, Kartal F, Vandepoele K, Inzé D, Beemster GTS (2007) Cold nights impair leaf growth and cell cycle progression in maize through transcriptional changes of cell cycle genes. Plant Physiology 143:1429-1438

Sadeghi H, Fardin K, Liela Y, Saman S (2011) Effect of seed osmopriming on seed germination behavior and vigor of soybean (Glycine max L.). ARPN. J Agric Biol Sci 6(1):39-43

Sanghera GS, Wani SH, Hussain W, Singh NB (2011) Engineering cold stress tolerance in crop plants. Curr Genom 12:30-43

Scott SJ, Jones RA, Williams WA (1984) Review of data analysis methods for seed germination. Crop Sci 24:1192-1199

Sharma P, Sharma N, Deswal R (2001) The molecular biology of the low temperature response in plants. BioEssays 27:1048-1059

Stewart CR, Martin BA, Reding L, Cerwick S (1990) Seedling growth, mitochondrial characteristics, and alternative respiratory capacity of corn genotypes differing in cold tolerance. Plant physiology 92:761-766

Takeoka Y, Mamun AA, Wada T, Kanj BP (1992) Reproductive adaptation of rice to environmental stress. Jpn Sci Soc Press 1:8-10

Wahid A (2007) Physiological implications of metabolites biosynthesis in net assimilationand heat stress tolerance of sugarcane (Saccharum officinarum) sprouts. J Plant Res 120:219-228

Wang Y, Huj T, Qin G, Cui H, Wang Q (2012) Salicylic acid analogues with biological activity may induce chilling tolerance of maize (zea mays) seeds. Botany 90:845-855

Williams PR, Congdon R, Grice AC, Clarke PJ (2004) Soil temperature and depth of legume germination during early and late dry season fires in a tropical eucalypt savanna of north eastern Australia. Austral Ecol 29:258-263

Xin Z, Browse J (2000) Cold comfort farm: the acclimation of plants to freezing temperatures. Plant, Cell and Environment 23:893-902. https://doi.org/10. 1046/j.1365-3040.2000.00611.x

Yuan X, Wen B (2018) Seed germination response to high temperature and water stress in three invasive Asteraceae weeds from Xishuangbanna, SW China. PLoS ONE 13(1):e0191710. https://doi.org/10.1371/journal.pone. 0191710

\section{Publisher's Note}

Springer Nature remains neutral with regard to jurisdictional claims in published maps and institutional affiliations. 